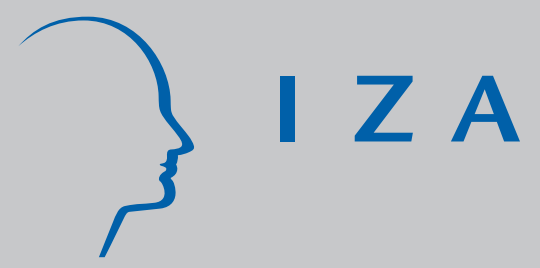

IZA DP No. 1084

Trade Liberalization and Labor-Demand Elasticities: Empirical Evidence from Tunisia

Ilham Haouas

Mahmoud Yagoubi

March 2004 


\title{
Trade Liberalization and Labor-Demand Elasticities: Empirical Evidence from Tunisia
}

\author{
Ilham Haouas \\ TEAM, University of Paris 1 \\ and IZA Bonn \\ Mahmoud Yagoubi \\ MATISSE, University of Paris 1
Discussion Paper No. 1084
March 2004

\author{
IZA \\ P.O. Box 7240 \\ 53072 Bonn \\ Germany \\ Phone: +49-228-3894-0 \\ Fax: +49-228-3894-180 \\ Email: iza@iza.org
}

\begin{abstract}
Any opinions expressed here are those of the author(s) and not those of the institute. Research disseminated by IZA may include views on policy, but the institute itself takes no institutional policy positions.
\end{abstract}

The Institute for the Study of Labor (IZA) in Bonn is a local and virtual international research center and a place of communication between science, politics and business. IZA is an independent nonprofit company supported by Deutsche Post World Net. The center is associated with the University of Bonn and offers a stimulating research environment through its research networks, research support, and visitors and doctoral programs. IZA engages in (i) original and internationally competitive research in all fields of labor economics, (ii) development of policy concepts, and (iii) dissemination of research results and concepts to the interested public.

IZA Discussion Papers often represent preliminary work and are circulated to encourage discussion. Citation of such a paper should account for its provisional character. A revised version may be available on the IZA website (www.iza.org) or directly from the author. 
IZA Discussion Paper No. 1084

March 2004

\section{ABSTRACT}

\section{Trade Liberalization and Labor-Demand Elasticities: Empirical Evidence from Tunisia}

This paper investigates the effects of trade liberalization on labor demand elasticities. Employment demand equation is estimated by using data (1971-1996) for manufacturing industries in Tunisia. Results from empirical testing using the model find a weak support for the idea assuming that trade liberalization will lead to an increase in labor demand elasticities: in the vast majority of the industries we consider, we cannot reject the hypothesis of no relationship between trade openness and labor-demand elasticities. This weakness of labor demand elasticity in practice is perhaps explained by the tight labor market regulations in place during the years 1987-96. However, our results are robust to the type of labor considered (contract labor and permanent labor). This supports the conclusion that in liberalization periods labor markets have become more flexible, and that employers prefer recruiting contract workers.

JEL Classification: F10, F12, J23, L60

Keywords: trade reforms, imperfect competition, factor demand elasticities, Tunisian manufacturing industries

Corresponding author:

Ilham Haouas

TEAM-CNRS

Universite Paris 1

Pantheon-Sorbonne

106-112 Bd. de l'Hôpital

75647 Paris cedex 13

Tel.: +33 144078242

Fax: +33144078337

Email: haouas@univ-paris1.fr 


\section{INTRODUCTION}

Trade reforms, even though considered to be walfare enhancing in the aggregate, do not have a uniform impact on all sections of society. Most economists like to think about the impact of these reforms in terms of their consequences for capitalists and workers. For example, in the presence of intersectoral factor mobility, opening up an economy to international trade in goods will help labor and hurt capital or vice versa, depending on whether to country's comparative advantage is in labor-or capital-intensive products. In fact, there is an important, ongoing debate on whether trade hurts or benefits unskilled labor relative to skilled worker (the owners of human capital), to which already many well-known scholars in the area have contributed ${ }^{1}$.

A new aspect of the trade-labor linkage that has received some attention in recent years is the impact of international trade in goods on labor demand: the possibility, particularly in imperfectly competitive contexts, for the elasticity of demand for labor to be higher with greater openness. The importance of this element of the labor-market impact of trade was first emphasized by Rodrick (1997). He argues that trade makes the demand for labor more elastic which in turn leads to larger employment and wage shocks as a result of given vertical shifts in the labor-demand curve (arising from shocks to productivity or to output demand). Also, this increase in elasticity leads to the erosion of the bargaining power of labor vis-à-vis capital in the sharing of supernormal profits. And finally, it also results in labor bearing a larger burden of the impact of non-wage labor costs. Thus, through this channel, workers are placed under greater pressure as a result of trade liberalization (see Slaughter (1997) for a detailed discussion of these effects). However, the vast majority of empirical literature has mainly a developed country focus. In contrast, the linkages between trade and labor markets are yet to be explored thoroughly in the context of developing countries. This paper takes a step in this direction by analyzing the relationship between labor markets and international trade in the Tunisian context.

Why does increase in openness lead to an increase in labor-demand elasticity?

The benefits to Tunisia form this trade liberalization should be substantial, and should pass through various channels (see Papi and Zazzaro, 2000). In addition, trade liberalization leads to lower prices for imported goods. Since Tunisia is an importer of capital equipment, and given complementarity between capital and employment, the employment rises. According to the standard theory of international trade, following integration, employment and total factor productivity should increase. First, the increases are a result of the better allocation of existing resources (the statistic effect) and the greater competitiveness of markets, goods, and factors, as well as the expansion of potential markets, and the full exploitation of scale and scope economies (the dynamic effect). Secondly, employment and efficient allocation of labor increase as a result of foreign and domestic investments stimulated by policies of trade liberalization. Thus, the advantages of foreign investments take the form not only of an immediate increase in aggregate demand, but also of knowledge transfers, opportunities to gain professional expertise, and commercial contracts.

However, employment benefits will pass through new investment, and the reallocation of production factors, to sectors with greater competitive advantages, and consequently, a general strategy for reform and modernization. A striking example of this is the plan for industrial restructuring and modernization (mise à niveau program). The aim of this plan is to prepare Tunisian manufacturing firms for the liberalization of markets and the greater

\footnotetext{
${ }^{1}$ Important contributions to the literature on the impact of globalization on wages and wages inequality have been made by Feenstra and Hanson (1996; 1997), and Hanson and Harrison (1999).
} 
competition that will arise. This program has been accompanied by generous tax breaks for investment in the exporting sector, progressive rationalization of the regulatory framework, and infrastructure development. To increase the flexibility of labor regulations, the labor code was revised in 1994, and again in 1996, to clarify the conditions under which workers can be laid off for cost saving reasons and to establish guidelines for financial compensation.

This paper attempts to investigate the link between trade openness and factor demand elasticities empirically. We start by specifying an econometrically implementable theoretical model of an industry operating in an imperfectly competitve context and derive predictions about the implications of changes in trade policy for labor demand elasticities. This is then tested using data from the Tunisian manufacturing sector from a period when there were scale changes in the level of trade protection (specifically, the trade reforms of 1986). This data set provides a unique opportunity to test the impact of trade policy on labor demand elasticities. It has several appealing features: First, if it is the case that greater openness generally results in larger factor demand elasticities, we should expect to see its effects after this particular reform ${ }^{2}$. Second, the data are of higher frequency than is typical: since manufacturing censuses are typically only conducted once every 3 or 5 year in most countries, one is usually only able to obtain two or three observations per industry in about a decade- a period over which there may typically be multiple shifts in trade policy. Thus, in most cases, extracting information about the impact of a signle shift in trade policy on industries is difficult. Our data, however, are annual, thus mitigating this concern. Third, this data set has already been used previously by Haouas, Yagoubi and Heshmati (2003) to examine labor use efficiency in manufacturing industries. It, thus, permits an industry-by-industry comparaison and concilitation of speed of adjustment with impact on labor markets.

Our analysis suggests that the linkage between greater trade openness and labor demand elasticities as suggested by the theory may be empirically quite weak: in the vast majority of the industries we considered, we are unable to reject the hypothesis of no relationship between these variables. As we discuss in detail in the paper, this finding remains robust to changes in the type of labor considered (all production workers, femal labor, etc.) and quite robust to changes in specification as well.

The rest of the paper is structured as follows. In section 2 some recent applications on developing countries are presented. Section 3 describes the Tunisian reforms briefly. Section 4 outlines the basic theoretical structure and derives the estimating equation. Section 5 describes the data. Section 6 discusses the primary econometric concerns and presents the econometric results. Section 7 discusses how we can reconcile our results with the finding of Haouas, Yagoubi and Heshmati (2003). Section 8 concludes.

\section{SOME RECENT APPLICATIONS ON DEVELOPING COUNTRIES}

There are few studies which in one or another way are relevant to the relationship between labor demand elasticities and trade liberalization in developing countries. In the following we briefly review a number of such studies.

Using industry-level data disaggregated by states, Hasan, Mitra and Ramaswamy (2003) finds a positive impact of trade liberalization on labor-demand elasticities in the Indian manufacturing sector. These elasticities turn out to be negatively related to protection levels that vary across industries and over time. Furthermore, they find that these elasticities are not

\footnotetext{
${ }^{2}$ In this regard, our study is set in a better context than the one examined by Slaughter (1997) whose focus instead is on US trade policy changes over the last decades which were rather less pronounced and more difficult to measure.
} 
only higher for Indian states with more flexible labor regulations; they are also impacted to a larger degree by trade reforms. Finally, he find that after reforms, volatility in productivity and outputs gets translated into larger wage and employment volatility, theoretically a possible consequence of larger labor-demand elasticities.

Fajnzylber and Maloney (2000) use establishment level data to provide consistent dynamic estimates of labor demand functions for three Latin American countries (Chile, Colombia, and Mexico) across trade policy regimes. The results show that estimates of elasticities do change greatly in magnitude, if not significantly so, over time and that comparisons across countries should take this into account when attempting to make inference about the flexibility or efficiency of labor markets. But more importantly, the data provide only very mixed support for the idea that trade liberalization has an impact on own wage elasticities and no consistent patterns emerge.

Using Turkish plant level data spanning the course of dramatic trade liberalization, Krishna, Mitra and Chinoy (2001) investigate empirically the link between trade openness and factor demand elasticities. Their analysis suggests that the putative linkage between greater trade openness and labor demand elasticities may be quite week. They explain this weakness by the variety of frictions that affect the labor demand decisions of firms.

\section{THE TUNISIAN REFORMS}

Like many countries in the region, Tunisia pursued a policy macroeconomic stabilization and exchange rate adjustment until the mid-1980s, where taxes on imports progressively increased and often exceeded 100 per cent of the import prices. During this period the manufacturing evolved through a highly regulated economic environment. These controls had a direct or indirect bearing on how the manufacturing sector used resources. In the labor market, for example, the government introduced minimum wages and adopted a rigid wage structure, which prevent a close linkage between base wages and performance-based bonus. Additionally, employers were prohibited to dismiss workers. Dismissal of workers should only take place following administrative approval by the government employment authorities. The effect is that laziness and absenteeism have become difficult to punish, resulting in lower productivity. Other than labor market controls, there ware practices of prices, foreign currency and investment controls as well.

However, the context became less favourable notably between 1984-1986, because of several negative factors (the fall in oil prices, the return of 30,000 workers who had immigrated to Libya, the conflicts between government and trade unions). These events and the emergence of a strong radical 'Islamic group' have constituted an obstacle for economic development. The political instability scared foreign and Tunisian investors and deterred them from creating projects, a fact which has reverberated negatively on growth and job creation. In addition, as the State continued a very important public investment policy despite these handicaps, it was obliged to borrow massively, including from commercial banks, so Tunisia was threatened by a financial crisis. This situation resulted in, the eviction of the President Bourguiba and his replacement by Prime Minister Ben Ali in November 1987. This political change allowed Tunisian authorities to accept conditions imposed by the World Bank and the IMF on exchange for financial assistance.

Since 1987, numerous measures have been taken to further liberalize international trade: the structural adjustment programme (1987), adherence to the General Agreement on Terms of Trade (1989), participation and signature to the Uruguay Round agreement (1993), adherence to the World Trade Organization (1994), and signing of a Free-Trade Agreement with the European Union (1995). According to Boudhiaf (2000), the consequences of these measures 
on international trade liberalization for Tunisia spread over three periods ${ }^{3}$. During the initial period of trade liberalization (1987-1990), the level of protection for the economy was greatly lowered. During the second period (1990-1995) the nominal and effective rate of protection increased in general except for some products. This increase is explained by the consequences of the Uruguay Round that transformed non-tariff protection into their tariff equivalent. Finally, during the third period (1995-1998), the nominal protection rate on agriculture increased, while the nominal protection rate for industrial products decreased significantly. The GATT $1994^{4}$ review of Tunisia's trade policies estimates the unweighted average legal tariff rate (including surcharges) at 33\%, and the range $0-73 \%$. This compares to ranges prior to reform of $5-236 \%$ and average tariff rate of $36 \%$ for the period $1981-1986$. The second liberalization period introduced major changes, mainly in import trade volume ${ }^{5}$ (see Table 1). It is against the background of policy changes outlined above that a study of the adjustment process of the impact of these reductions in trade protection on labor markets becomes essential $^{6}$.

Table 1. Tunisian manufacturing industries: effective protection rate and import volumes.

\begin{tabular}{|l|c|c|c|c|c|c|}
\hline \multirow{2}{*}{ Industry } & \multicolumn{3}{|c|}{ Effective protection rate $^{a}$} & \multicolumn{3}{c|}{ Imports (Millions of dinars) $^{b}$} \\
\cline { 2 - 7 } & 1986 & 1990 & 1995 & 1986 & 1990 & 1996 \\
\hline Food & $421 \%$ & $100 \%$ & $115 \%$ & 236 & 272.7 & 321.9 \\
\hline Construction material \& ceramic & $40 \%$ & $82 \%$ & $85 \%$ & 53.7 & 69.8 & 76.8 \\
\hline Mechanical electric industry & $88 \%$ & $101 \%$ & $169 \%$ & 1683.2 & 1952.8 & 1973 \\
\hline Chemical & $88 \%$ & $78 \%$ & $65 \%$ & 524.5 & 619.6 & 585.6 \\
\hline Textile, clothing \& leather & $194 \%$ & $73 \%$ & $132 \%$ & 612.6 & 991.2 & 1316.2 \\
\hline Other manufacturing & $101 \%$ & $80 \%$ & $102 \%$ & 244.3 & 486.8 & 439 \\
\hline
\end{tabular}

Source : $a$. Boudhiaf (2000), "Politique tunisienne d'ouverture commerciale". IRD, 9 juin.

$b$. National accounts from the Tunisian National Statistic Institute (INS) and statistics from the Quantitative Economy Institute (IEQ).

\section{THEORY AND ESTIMATION FRAMEWORK}

To demonstrate theoretically how changes in trade policy resulting in greater product market competition and larger product market elasticities, and to establish theoretical underpinnings for the empirical work to follow, we work with a model of monopolistic competition, where each firm faces its own less than infinitely elastic demand curve and where there is assumed to be no strategic interaction between firms ${ }^{7}$. Thus, any firm $i$ in industry $j$ is assumed to face an inverse demand curve of the type:

$$
P_{i j}=\theta \bar{P}_{j} Q_{i j}^{-1 / \epsilon}
$$

\footnotetext{
${ }^{3}$ For evaluation of the effects of trade liberalization on employment and wages in other developing countries, see Brecher (1974), Levinsohn (1999), and Beyer et al. (1999).

${ }^{4}$ GATT (1994), TPRM, for unweighted average tariff rates and ranges.

${ }^{5}$ Of course issues of counterfactuals and causality arise. The expansion of exports may have been positively influenced (in part at least) by other external and non-policy factors.

${ }^{6}$ According to Lakhoua (1998) these reforms have been accompanied by important social achievements; these include intensification of job creation, income seems to be more evenly distributed than in most comparable countries and the incidence of poverty to be correspondingly low.

${ }^{7}$ This approximates a situation in which there are a large number of varieties and each firm is an infinitesimal player but has some power over the pricing of its product.
} 
where $P_{i j}$ denotes own price, $\bar{P}_{j}$ denotes industry average price, $\theta$ is a scaling factor, $Q_{i j}$ denotes firm output and $\in$ denotes the (constant) price elasticity of demand. The production function is assumed to be a Cobb-Douglas type (in variable inputs), and given by:

(2) $\quad Q_{i j}=\prod_{k=1}^{n} V_{k i j}^{\alpha_{k}}$

where $V_{k i j}$ denotes $k$ th input in use here.

The firm is assumed to face infinitely elastic factor supplies, i.e., it takes factor prices as given. Partially differentiating profits with respect to the $l$ th input and equating it to zero gives us the following first order condition:

$$
\theta \bar{P}_{j} Q_{i j}^{1-1 / \epsilon}\left(1-\frac{1}{\epsilon}\right) \alpha_{l} V_{l i j}^{-1}=w_{l}
$$

where $w_{l}$ denotes the price of the $l$ th input. In log form, (3) can be rewritten as:

$$
\ln V_{l i j}=\gamma_{0}+\gamma_{1} \ln \left(\frac{w_{l}}{\overline{P_{j}}}\right)+\sum_{k \neq 1} \gamma_{k} \ln V_{k i j}
$$

where the $\gamma$ values are each a function of $\in$. Substituting the FOC for other inputs back into (4) above, we get:

$$
\ln V_{l i j}=\delta_{0}+\sum_{k=1}^{n} \delta_{k} \ln \left(w_{k} / \overline{P_{j}}\right)
$$

which is a demand function for the $l$ th input expressed in terms of the variables the firm takes as exogenous - factor prices and the industry average price. The coefficients in the above equation are function of $\in$. The own price elasticity of an input is given by:

$$
\frac{\partial \ln V_{l i j}}{\partial \ln \left(w_{l} / \overline{\left.P_{j}\right)}\right.}=\delta_{l}=\frac{-\left[1-\left(1-\frac{1}{\epsilon}\right)\left(\sum_{k \neq 1} \alpha_{k}\right)\right]}{\left[1-\left(1-\frac{1}{\epsilon}\right)\left(\sum_{k=1}^{n} \alpha_{k}\right)\right]}
$$

The derivative of the absolute value of the own price elasticity of input demand with respect to the product demand elasticity is given by :

$$
\frac{\partial\left|\delta_{1}\right|}{\partial \in}=\frac{\alpha_{l}}{\epsilon^{2}\left[1-\left(1-\frac{1}{\epsilon}\right)\left(\sum_{k=1}^{n} \alpha_{k}\right)\right]^{2}}>0
$$


which shows the magnitude of the own price elasticity of factor demand is increasing in the product demand elasticity (thus proving that the effects predicted by Hick's Law are relevant in this context). The cross-price elasticity of demand for inputs may be analogously derived and is given by:

$$
\frac{\partial \ln V_{l i j}}{\partial \ln \left(w_{s} / \overline{\left.P_{j}\right)}\right.}=\delta_{s}, \quad s \neq 1
$$

We now specialize to the case where the only inputs are labor, capital, and energy. Additionally, we let $w, r, m$ and $f$ denote the logs of the wage rate, the rental rate, capital price and energy price, respectively, and each deflated by the industry-level average output price. Finally, we focus our attention on the demand for labor alone (as opposed to that for other factor inputs) ${ }^{8}$. The labor demand function is then given by:

$$
l_{i j t}=\delta_{0}+\delta_{w} w_{i j t}+\delta_{r} r_{i j t}+\delta_{m} m_{i j t}+\delta_{f} f_{i j t}
$$

where $l$ is the log of labor demanded. Thus, our final estimating equation is

$$
l_{i j t}=\delta_{0}+\delta_{w} w_{i j t}+\delta_{r} r_{i j t}+\delta_{m} m_{i j t}+\delta_{f} f_{i j t}+e_{i j t}
$$

where the error term $e_{i j t}$ allows for random shocks to affect the firm's demand for labor.

\section{THE DATA}

The data used in this study has been assembled using a diversity of sources (national accounts from the Tunisian National Statistic Institute (INS) and statistics coming from the Quantitative Economy Institute (IEQ) and central bank of Tunisia). We did so in order to allow the construction of an integrated database of industrial, labour market and trade statistics feasible. Thus we have a panel on 6 manufacturing industries from 1971 to 1996. The data are annual. These 6 industries are included in the free trade agreement of 1995 between Tunisia and the European Union. The industries included are food industry, textiles, clothing and leather industry, chemical industry, construction material, ceramic and glass industry, mechanical electric industry, and other manufacturing industry (including paper and pulp, plastics, etc). Table 1 lists the volume of import and effective protection rate by industry.

Our interest in this paper is in labor market effect of trade liberalization. To estimate equation (10), we need data on input prices faced by the firm and labor employed. The dependent variable is measured as total employment in each industry $(L)$. For robustness, we also estimate (10) using other categories of labor, specifically, contract workers, and permanent workers ${ }^{9}$. The independent variables in the labor demand part of the model are average wages

\footnotetext{
${ }^{8}$ The theory clearly applies to all input factors. However, we focus only on labor demand since any effort estimating demand equations for other factors would be frustrated by the fact that firm level data on the use of the other factors and/or factor prices is not available.

${ }^{9}$ Using the annual survey on firms made by the INS derived permanent and contract workers.
} 
$(w)$, capital price $(m)^{10}$, and energy price $(f)$. Economy-wide interest rate data (borrowing costs) were used as rental costs. ${ }^{11}$

Wages are defined as average annual wage per worker. It is obtained by dividing total wages in each industry by the total number of employees in that industry. Thus, the wage variable is industry specific. The average wages are then transferred to fixed 1971 prices using the producer price index. Wages, material price and energy price are given in Tunisian Dinars.

\section{EMPIRICAL ANALYSIS}

As described in the introduction, a more liberal trade policy may be expected to raise labordemand elasticity. We now examine the evidence for these possibilities. Equation (10) derived in the previous section is our basic estimating equation. We begin by considering OLS estimates of the own price labor demand elasticity, the cross capital price labor demand elasticity, and the own price labor demand elasticity by worker type separately for each industry. However, without adequately controlling for other policies, one risks confounding the effects of trade liberalization with other structural reforms. Also, there may be severe endogeneity problems- unobserved demand shocks may not be orthogonal to trade intensity so that OLS estimates may be biased and inconsistent. This requires that we use a fixed effects model. To take into account the unobserved sectorel variation we use industry-specific fixed effect dummies. We capture the effects of trade liberalization on the parameters in (10) by the use of a liberalization dummy, which takes the value 0 up to 1986 and 1 thereafter.

\subsection{Labor Demand Elasticities with Respect to Wages}

Table 2 presents results for labor demand elasticities and their changes in each of the 6 industries, under the fixed effects and random effects models. The estimated elasticities $\left(\delta_{w}\right)$ lie within the range of $-0,213$ to $-0,453$. Thus, this fall well within what Hammermesh (1993) has identified as being a reasonable range of values for labor demand elasticities. In the six cases, across both types of estimates, the elasticity estimates are quite tightly estimated and in line with previous studies.

The parameter of interest here is elasticity change, i.e., the parameter corresponding to the wage variable interacted with the liberalization dummy $\left(\Delta \delta_{w}\right)$. As the columns 2 and 4 in the Table 2 indicate, our estimates of the interaction term involving wages and the post-1986 dummy are small in magnitude and largely insignificant. In four out of 6 cases, under both OLS and fixed effects estimates, the null hypothesis that the change in elasticity after the reforms is zero cannot be rejected at the 5\% level or indeed in most cases at even a higher level of significance. The two industries where the null hypothesis of no elasticity change is rejected are chemical and textile, clothing and leather. In these cases the $\Delta \delta_{w}$ estimate is negative and positive, implying that the absolute value of the own price labor demand elasticity goes up. It appears thus in the vast majority of the industries considered separately we are unable to find statistically and economically significant relationship between these variables.

\footnotetext{
${ }^{10}$ Capital price is assumed equal to the price of acquiring new capital or PFCFB ("prix de formation de capital fixe par branche d'activité")

${ }^{11}$ We find that the results are mostly invariant to the assumptions regarding interest rates. This is discussed in more detail in the next section.
} 
Table 2. Own price labor demand elasticity estimates

\begin{tabular}{lllllllll}
\hline \multicolumn{1}{c}{ Industry } & \multicolumn{3}{c}{ Fixed effects } & \multicolumn{3}{c}{ OLS estimates } \\
& \multicolumn{2}{c}{$\delta_{w}$} & \multicolumn{2}{c}{$\Delta \delta_{w}$} & \multicolumn{2}{c}{$\delta_{w}$} & \multicolumn{2}{c}{$\Delta \delta_{w}$} \\
\hline Food & -0.302 & $(0.031)$ & -0.010 & $(0.038)$ & -0.223 & $(0.021)$ & 0.011 & $(0.070)$ \\
Construction material and ceramics & -0.396 & $(0.042)$ & 0.007 & $(0.024)$ & -0.295 & $(0.035)$ & -0.012 & $(0.092)$ \\
Mechanical electric industry & -0.312 & $(0.047)$ & -0.002 & $(0.212)$ & -0.293 & $(0.057)$ & 0.009 & $(0.070)$ \\
Chemical & -0.453 & $(0.024)$ & -0.046 & $(0.021)$ & -0.448 & $(0.029)$ & -0.053 & $(0.026)$ \\
Textile, clothing and leather & -0.213 & $(0.080)$ & 0.029 & $(0.012)$ & -0.197 & $(0.038)$ & 0.042 & $(0.013)$ \\
Other manufacturing & -0.263 & $(0.020)$ & 0.003 & $(0.070)$ & -0.201 & $(0.024)$ & -0.008 & $(1.254)$ \\
$\mathrm{R}^{2}$ & 0.776 & & 0.667 & & 0.698 & & 0.453 & \\
\hline
\end{tabular}

Notes: figures in parentheses are standard errors.

This lower responsiveness of labor demand elasticities to trade liberalization was expected because of the job security regulations in force. Employers could not easily fire workers, even if there were increase in wage costs. Despite recent progress government role is still important and the number of layoffs is still controlled for both private and public firms. Despite the recent reform of the labor code the time required to obtain a retrenchment for economic reasons remains long in practice, hampering necessary restructuring.

Several issues regarding the validity of the estimation framework and the interpretation of the results arise. First in the familiar issue of possible simultaneity and correlation between the error term and the right-hand side variable. Since both labor demand and labor supply depend upon the wage, shocks to the labor demand will result in shocks to the wage ${ }^{12}$. Thus the wage and the disturbance term in our estimating equation may be correlated, thereby raising the possibility of bias in our estimates.

The second issues concerns that of timing and lagged responses. It is assumed in our estimation of (10) that firm demand response to changes in wage occurred without lags. As Hammermesh (1993) has noted, much of the adjustment in firm labor demand takes place within 6 months to 1 year. Thus, given that our data are annual, this is not a serious problem.

A third issue is that data indicate that the measured wage is quite different across industries. We believe that this reflects unobserved differences in worker quality across industries or to a smaller extent due to differences in the number of hours on the job put in by workers in different industries. Given such differences, it will be reasonable to expect that labor demand itself could be somewhat different across industries. Of course, to the extent that the differences are simply in levels and are fixed over time - our industry specific intercept should take care of the problem.

\subsection{Labor Demand Elasticities with Respect to Capital Price}

Cross capital price elasticities (of labor demand) and their changes following the trade reform were not estimated with great precision. Hardly any of the estimates were significant at the $5 \%$ level or even at higher levels. OLS and Fixed effects estimates of the cross capital price labor demand elasticity estimates are presented in Table 3. The estimated elasticities range 'between' 0.012 to -8.047 , but only three cases are statistically significant. We are not greatly surprised by these estimates and their lack of significance- with few exceptions; the literature has traditionally found cross price elasticities to be rather difficult to estimate.

\footnotetext{
${ }^{12}$ To the extend that, say, aggregate demand or productivity shocks increase product demand and raise labor demand and increase wages (or any other factor prices for that matter) at the same time, the elasticity estimates delivered from equation (6) would be biased due to the correlation between the error term and the right-hand side variable.
} 
As the Table 3 indicates, our estimates of the changes in labor demand elasticities $\left(\Delta \delta_{m}\right)^{13}$ are largely insignificant. Under both the OLS and fixed effects estimates, there are only two industries were the null hypothesis of no elasticity change is rejected. These industries are Chemical and Mechanical electric industry.

Tableau 3. Cross capital price labor demand elasticity estimates

\begin{tabular}{llllllllll}
\hline Industry & \multicolumn{3}{c}{ Fixed effects } & \multicolumn{3}{c}{ OLS estimates } \\
& \multicolumn{2}{c}{$\delta_{m}$} & \multicolumn{2}{c}{$\Delta \delta_{m}$} & & $\delta_{m}$ & & $\Delta \delta_{m}$ \\
\hline Food & 3.172 & $(3.127)$ & 2.007 & $(1.869)$ & 3.125 & $(3.138)$ & 1.836 & $(1.184)$ \\
Construction material and ceramics & 0.234 & $(0.932)$ & 0.017 & $(0.980)$ & 0.214 & $(0.920)$ & 0.013 & $(0.635)$ \\
Mechanical electric industry & -8.047 & $(3.014)$ & -2.033 & $(1.015)$ & -7.045 & $(2.015)$ & -2.036 & $(1.011)$ \\
Chemical & -2.213 & $(1.124)$ & -1.717 & $(0.673)$ & -2.002 & $(0.828)$ & -1.058 & $(0.370)$ \\
Textile, clothing and leather & 1.458 & $(0.851)$ & 0.558 & $(0.381)$ & 1.326 & $(0.727)$ & 0.226 & $(0.474)$ \\
Other manufacturing & 0.012 & $(0.017)$ & 0.007 & $(0.020)$ & 0.011 & $(0.055)$ & 0.004 & $(0.081)$ \\
$\mathrm{R}^{2}$ & 0.753 & & 0.592 & & 0.665 & & 0.489 & \\
\hline
\end{tabular}

Notes: figures in parentheses are standard errors.

\subsection{Labor Demand Elasticities (and changes) by Worker Type}

For robustness (and also independent interest in variations in labor demand elasticities across worker types), we estimate equation (10) by considering the demand for contract workers and permanent workers separately. The elasticities again are quite tightly estimated (see Table 4). However, as expected, their values are higher in magnitude than the ones for overall labor as substitution possibilities are higher when we look at specific kinds of labor than in the case of labor in general. For contract workers, most elasiticity estimates are between -1 and -3 , while for permanent workers, labor demand seems to be inelastic. Changes in elasticity are again mostly insignificant following the reforms: significant negative value for $\Delta \delta_{w}$ are produced in Food for permanent workers, and significant positive values are produced in Food, Textile, clothing and leather, and Other manufacturing for contracts workers.

The positive association between wage and contract labor in these sectors can be explained by labor regulation reforms. In fact, to increase flexibility of labor regulations, the Tunisian labor code was revised in 1994 and 1996. As a result, in some sectors, fixed term contracts and subcontractual arrangements now account for $90 \%$ of labor contracts ${ }^{14}$. Contracts labor seems to be the obligated passage to enter in labor markets and it is absolutely correlated with the unemployment of younger people in Tunisia.

Tableau 4. Own price labor demand elasticity by worker type: fixed effects estimates

\begin{tabular}{lccccccccc}
\hline & \multicolumn{3}{c}{ Contract worker } & \multicolumn{3}{c}{ Permanent worker } \\
Industry & \multicolumn{2}{c}{$\delta_{w}$} & \multicolumn{2}{c}{$\Delta \delta_{w}$} & \multicolumn{3}{c}{$\delta_{w}$} & & \multicolumn{2}{c}{$\Delta \delta_{w}$} \\
\hline Food & -1.282 & $(0.231)$ & 0.246 & $(0.113)$ & -0.761 & $(0.408)$ & -0.242 & $(0.072)$ \\
Construction material and ceramics & -2.618 & $(0.405)$ & -0.502 & $(0.487)$ & -0.374 & $(0.234)$ & -0.381 & $(0.263)$ \\
Mechanical electric industry & -0.832 & $(0.052)$ & -0.099 & $(0.063)$ & -0.247 & $(0.155)$ & 0.577 & $(0.847)$ \\
Chemical & -1.883 & $(0.199)$ & -0.163 & $(0.071)$ & -0.359 & $(0.147)$ & 0.277 & $(0.157)$ \\
Textile, clothing and leather & -2.915 & $(1.303)$ & 1.187 & $(0.638)$ & -1.112 & $(0.134)$ & -0.050 & $(0.367)$ \\
Other manufacturing & -1.144 & $(0.155)$ & 0.154 & $(0.053)$ & -0.856 & $(0.262)$ & -0.231 & $(0.261)$ \\
$\mathrm{R}^{2}$ & 0.786 & & 0.656 & & 0.776 & & 0.623 & \\
\hline
\end{tabular}

Notes: figures in parentheses are standard errors.

\footnotetext{
${ }^{13}$ This parameter correspond to the capital price variable interacted with the liberalization dummy.

${ }^{14}$ Indeed, we indicate that Tunisian labor regulation allows firms to recruit by fixed term contracts and seasonal personnel, and to dismiss them without any indemnity at the end of their contract.
} 


\subsection{Results of Estimation Using Data Pooled Across Industries}

Our penultimate set of regressions used data pooled across all the 6 manufacturing industries. The results are presented in Table 5. As noted earlier, this was done with the intention of using instrumental variables techniques to control for any remaining simultaneity problems in the framework ${ }^{15}$. Pooling of the data also allows us to use variations in cross industry changes in import penetrations ratios as proxies for the reform dummies ${ }^{16}$.

We start first with estimates of equation (10) using pooled data and using lagged right-hand side variables as instruments (Regression 1). The IV estimates for the pooled sample gives us an elasticity that is not as precisely estimated (although the point estimate appears to be in a reasonable quantitative range) and again we cannot reject the null that the trade reform did not have any effect on the labor demand elasticity. The point estimate of change in elasticity is economically insignificant.

Regression 2 uses import penetration interactions (impp). The coefficient of the cross product of impp and the log of wage gives us $\partial \delta_{w} / \partial(i m p p)$, the derivative of the labor demand elasticity with respect to the import-penetration ratio. The labor demand elasticity at zero import penetration, $\delta_{w}$, is significantly estimated to be -0.711 . The estimate for $\partial \delta_{w} / \partial($ impp $)$ is -0.213 and is significant at $1 \%$. Surprisingly and counter-intuitively, the sign of this coefficient shows that higher imports are associated with higher magnitude of labor demand elasticities. In this regard, Haouas, Yagoubi and Heshmati (2002) find a positive effect of import on employment. They explain this result by the fact that Tunisia is an importer of manufactured goods. The complementarity between capital and employment is a factor that explains the rise in employment following an increase in import.

Tableau 5. Labor demand elasticity estimates over all industries

\begin{tabular}{cccc}
\hline \multicolumn{2}{c}{$\begin{array}{c}\text { Regression 1 } \\
\text { (Instrumental variable estimates with time dummy } \\
\text { interactions }\end{array}$} & \multicolumn{2}{c}{$\begin{array}{c}\text { Regression 2 } \\
\text { (Instrumental variable estimates with import penetration) }\end{array}$} \\
\hline$\delta_{w}$ & $-0.634(0.650)$ & $\delta_{w}$ & $-0.711(0.098)$ \\
$\Delta \delta_{w}$ & $-0.263(0.178)$ & $\partial \delta_{w} / \partial($ impp $)$ & $-0.213(0.014)$ \\
\hline
\end{tabular}

\section{RECONCILIATION WITH THE Haouas, Yagoubi and Heshmati (2003) RESULTS}

Our finding that greater trade openness did lead to significant labor demand elasticities in Tunisia at first thought seems somewhat consistent with Haouas, Yagoubi and Heshmati's (2003) finding. In fact, if the two industries where the null hypothesis of no elasticity change is rejected are chemical and textile, clothing and leather, this is no surprise. Haouas, Yagoubi and Heshmati (2003) find that Chemical and textile, clothing and leather are the most

\footnotetext{
${ }^{15}$ While instrumental variables estimation is perhaps a more satisfactory approach, it proves a little less feasible in this context: other than lagged endogenous variables, we have no variable in the data set that we may regard as being exogenous. Estimating (10) using lagged variables as IVs resulted in highly insignificant (and sometimes meaningless) estimates of the parameters of interest. One option that presents itself then is the pooling of data across industries to use lagged variables as instruments. These results are presented in Table 5 and are discussed later along with other results from the pooled sample.

${ }^{16} \mathrm{We}$ are should to note some caveats associated with pooling data across industries:
} 
inefficient in the use of labor ${ }^{17}$. This inefficiency can be explained by the extensive utilisation of human capital. The technical infrastructure is used only partially. Industries less efficient would be expected to adjust faster (as they try to eliminate their inefficiency faster) than those most efficient. In other words, industries closer to the labor requirement frontier would be expected to have a lower speed of adjustment after liberalization than industries farther away from it.

Results from Haouas, Yagoubi and Heshmati (2003) indicate that chemical and textile, clothing and leather adjust faster under the liberalization period than the other sector ${ }^{18}$.

In fact the negative correlation between labor and capital price in Chemical and Mechanical electric industry industries after trade liberalization can be explained by the structural change favourable to branches that made intensive use of skilled worker and technology as opposed to sectors with intensive use of unskilled labor. Consequently, the number of production workers- a larger category of workers in Tunisian industries- decreased, while skilled labor- a small category- increased. As Haouas, Yagoubi and Heshmati (2003) indicate, the production process in these sectors becomes capital intensive after trade liberalization.

\section{CONCLUSION}

Our analysis of the impact of trade reforms on labor demand elaasticities using industry level data over a period spanning major trade reforms in the Tunisian economy suggests that the putative linkage between greater trade openness and labor demand elesticities (as suggested by theories of the type we present in this paper) may empirically quite weak: in the vast majority of the industries we considered separately, we are unable to find statistically and economically significant relationship between these variables. Our results are robust to the type of labor considered (contract labor and permanent labor). This non-responsiveness of labor demand elasticity in practice is perhaps explained by the tight labor market regulations in place during the 1987-1996. However, the results, indicated above, support the conclusion that under the liberalization period labor markets have become more flexible, and that employers are able to recruit contracts worker in some sectors.

These findings have important implications for public policy and highlight some challenge for policy-making. Although our results suggest that tighter labor regulations-through restrictions on retrenchments and layoffs, for example, - can dampen change in labor elasticities, it is hard to believe that more widespread use of such regulations is the desirable policy response. Particularly in the context of Tunisia's growing integration with the international economy, allowing Tunisian firms to be exposed to import competition but constraining their ability to adjust their inputs in response is likely to put domestic firms at a serious disadvantage in terms of their ability to compete.

\footnotetext{
${ }^{17}$ For a given level of value added, chemical could be better of by reducing employment by $63,8 \%$ and textile by $59,8 \%$

${ }^{18}$ Employment adjustment is $23 \%$ in chemical industry and 6,1\% in textile industry.
} 


\section{REFERENCES}

Boudhiaf, M. 2000."Politique tunisienne d'ouverture commerciale". Paper presented at Séminaire internationale, Perspectives de l'économie tunisienne dans le cadre de l'ouverture régionale. IRD, 9 June.

Beyer H., P. Rojas and R. Vergara. 1999. "Trade Liberalization and Wage Inequality". Journal of Development Economics, 59: 103-123.

Brecher R. A. 1974. "Minimum Wage Rates and the Theory of International Trade". Quarterly Journal of Economics, 88: 98-116.

Fajnzylber, P. and F.W. Maloney. 2000. "Labor Demand and Trade Reform in Latin America”. Policy Research Working Paper, 2491. World Bank, Washington, D.C.

Feenstra, R. and G. Hanson. 1997. "Productivity Measurement and the Impact of Trade and Technology on Wages: Estimates for the U.S., 1972-1990,”. NBER Working Paper, 6052.

Feenstra R. and G. Hanson. 1996. "Globalization, Outsourcing, and Wage Inequality". American Economic Review, 86 (2): 240-245.

Hamermesh, D. S. 1993. Labour demand, Princeton, New Jersey.

Hanson G.H. and A. Harrsion. 1999. "Trade Liberalization and Wage Inequality in Mexico". Industrial and Labor Relations Review, 52(2): 271-288.

Haouas I., M. Yagoubi and A. Heshmati 2003. "Labour-Use Efficiency in the Tunisian's Manufacturing Industries: A Flexible Adjustment Model". Review of Middle East Economics and Finance, $\mathrm{n}^{\circ} 3$.

Haouas, I., M. Yagoubi and A. Heshmati. 2002. "The Impacts of Trade Liberalization On Employment and Wages in Tunisian Industries". WIDER Discussion Paper, 2002/102. Helsinki.

Hasan, R., D. Mitra and K.V. Ramaswamy. 2003. "Trade reforms, Labor Regulations and Labor-Demand Elasticities: Empirical Evidence From India”. NBER Working Paper, 9879.

Kambhampati, U., P. Krishna, and D. Mitra 1997. "The Impact of Trade Policy Reforms on Labor Markets: Evidence from India". Journal of International Trade and Economic Development, 6 (2): 287-299.

Krishna P., D. Mitra. and S. Chinoy. 2001. "Trade Liberalization and Labor Demand Elasticities: Evidence From Tukey". Journal of International Economics, 1: 1-19.

Lakhoua, F. 1998. "The Tunisian Experience of "Mise à niveau": Conceptual Issues and Policy Orientations", Paper Presented at the MDF II. Marakech, September.

Levinsohn J. 1999. "Employment responses to international liberalization in Chile", Journal of International Economics, 47: 321-344.

Papi, L. and A. Zazzaro 2000. "How Does The EU Agenda Influence Economies outside the EU? The Case of Tunisia". Development Studies Working Papers, 148. Centro Studi Luca D'Agliano, Italy.

Rodrik, D.1997. "In: Has Globalization Gone Too Far? ". Institute for International Economics, Washington, DC.

Slaughter, M. 1997. "International Trade and Labor Demand Elasticities". NBER Working Paper, 6262. 